DOI 10.18551/rjoas.2021-07.19

\title{
THE INFLUENCE OF EXTENSION WORKER CHARACTERISTICS, MOTIVATION AND ORGANIZATIONAL CLIMATE ON PERFORMANCE OF AGRICULTURAL EXTENSION WORKER ON IMPLEMENTATION OF SERASI PROGRAM IN TANJUNG LAGO SUBDISTRICT REGENCY OF BANYUASIN SOUTH SUMATRA, INDONESIA
}

\author{
Wulandari Linda \\ Master's Program of Agribusiness, Faculty of Agriculture, University of Sriwijaya, \\ Palembang, Indonesia \\ Sriati ${ }^{\star}$, Riswani \\ Faculty of Agriculture, University of Sriwijaya, Palembang, Indonesia \\ *E-mail: sriati@unsri.ac.id
}

\begin{abstract}
Serasi Program (Selamatkan Rawa Sejahterahkan Petani) is one of the programs carried out to optimize swamp land so that rice production can increase. One of the areas that implements the Serasi program in 2019 is Banyuasin precisely in Tanjung Lago Sub-district. Extension becomes a resource that bridges information from the Government to farmers. The purposes of this study are: (1) Measure the performance of agricultural extension in Tanjung Lago Subdistrict, (2) Analyze the influence of extension characteristics on the performance of agricultural extension workeron the implementation of the Serasi program in Tanjung Lago Subdistrict, (3) Analyze the influence of motivation on the performance of agricultural extension in the implementation of the Serasi program in Tanjung Lago Subdistrict, (4) Analyze the influence of the organization's climate on agricultural extension performance in the implementation of the Serasi program in Tanjung Lago Subdistrict. This research was conducted in Tanjung Lago Subdistrict, Banyuasin Regency. Data collection is conducted from February to April 2021. The sample number of 108 people consisting of 9 field agricultural extension workers (PPL) and 99 farmers was determined through multistage sampling. PPL is taken by census from PPL in Tanjung Lago Subdistrict involved in the Serasi Program. Farmer samples were taken randomly from Gapoktan in 9 PPL assisted villages, 11 farmers each. The data in the analysis uses variable indicator measurement methods and statistical analysis using Smart PLS version 3.0. The results showed: (1) the performance of extension workers in Tanjung Lago Subdistrict has an average score of 46.06 with an very good category; (2) The karaterikstic factor of extension has a positive and significant effect on the performance of agricultural extension (3) Motivational factors positively and significantly affect the performance of agricultural extension (4) The organization's climate factors positively and significantly affect the performance of agricultural extension.
\end{abstract}

\section{KEY WORDS}

Agricultural extension, extension worker characteristics, motivation, organizational climate, serasi program.

Agricultural development programs in all aspects are a series of efforts that are able to improve the economy and standard of living of the community, especially rural communities. Human resource support in this case superior agricultural extension can support government programs in the field of agriculture and able to encourage and help farmers' lives become prosperous. Counseling is organized based on democracy, benefits, equality, cohesion, balance, openness, cooperation, participatory, partnership, sustainable, fairness, equality, and accountability as stated in article 2 of UU No. 16 of 2006 on SP3K. The main purpose of agricultural extension is to change the behavior of farmers so that they are expected to manage their farming productively, effectively and efficiently. According to Padmanagara 
(2012) the purpose of counseling is to help and facilitate farmers and their families to achieve a more efficient and productive level of farming. The principle of agricultural extension is the effectiveness of agricultural extension methods and techniques so as to change the behavior of farmers, especially in the adoption of technological innovations.

Counseling activities in agricultural development serve as a bridge that connects between the practices run by farmers with the knowledge and technology of agriculture that is always evolving. Agricultural extension activities conducted by farmers become one of the success factors of agricultural development, because counseling is present as a boost for agricultural development. The performance of an extension can be seen from individual characteristics and the influences of situational such as motivation and organizational climate in the implementation of agricultural extension in each district (Leilani and Jahi, 2016).

In 2019 the Ministry of Agriculture implemented a Serasi Program (Selamatkan Rawa Sejahterakan Petani) Program that will utilize tidal swamp land in South Sumatra, South Kalimantan, and South Sulawesi. The focus of the Serasi Program activities includes improving the infrastructure of the water system network, embankments, farm roads, floodgates, pumping, alsintan, and saprodi. In addition to rice crops, in this Serasi program will be developed other commodities such as fish, duck cattle, horticultural crops vegetables and oranges, so that there is a diversification of farmers' income. With the Serasi Program is expected to be able to make tidal swamp land as a food barn of Indonesia and improve the welfare of farmers.

Banyuasin regency is one of the regencies in South Sumatra has managed to maintain food security by becoming the number one rice production center in South Sumatra Province. In 2020, Banyuasin district managed to produce as much as 519 thousand tons of rice so banyuasin entered into the top four of the top 10 nationally as a food contributor district in Indonesia. One of the government's efforts to increase rice production is to implement the Serasi Program (Selamatkan Rawa Sejahterakan Petani). The Serasi program focuses on swampland development to be used as land to grow rice so that the goal of increasing rice production and maturity through increasing crop index and productivity, especially in swamp land can be achieved (Pedoman Teknis Optimasi Lahan Rawa , 2019).

Tanjung Lago subdistrict is one of the areas in Banyuasin Regency that participated in the Serasi program with a total of 9 villages involved. One of the keys to the success of the Serasi Program that aims to increase the productivity of rice farmers in Tanjung Lago Subdistrict is the involvement of parties or extension institutions located in the center and in the region. According to Wahjuti (2007), one form in the development of human resources agriculture that determines the success of the development of agricultural development programs is agricultural extension because it is directly related to farmers as the main actors and other business actors. This shows the importance of PPL's role in the implementation and success of programs related to farmers and their farming, as well as the Serasi program.

The success of the Serasi rogram is a good indication of the performance of agricultural extension workerin carrying out the extension main tasks and functions seen from the behavior (knowledge, attitude and skills) of farmers in the implementation of the Serasi program. The success of the implementation of ppl role tends to be seen from changes in farmer behavior in an effort to increase rice productivity in accordance with the potential of the region. Based on the description above, the role of Field Agricultural Extension is an interesting aspect to be researched, the performance of Field Agricultural Extension is a field officer who is directly related to farmers and as a medium in the transfer of information in the field of agriculture. Extension of Field Agriculture as a bridge between farmers and new programs or technologies. But to know the extent of the influence of extension characteristics, motivation and climate of the organization on the performance of agricultural extension workeron the implementation of the Serasi program is required an in depth study. Based on the above affairs, the objectives in this study are: (1) Measuring the performance of agricultural extension workerin Tanjung Lago Subdistrict, Banyuasin Regency. (2) Analyzing the influence of extension characteristics on agricultural extension performance in the implementation of the Serasi program in Tanjung Lago Subdistrict, Banyuasin Regency. (3) Analyzing the influence of motivation on agricultural extension 
performance in the implementation of the Serasi program in Tanjung Lago Subdistrict, Banyuasin Regency. (3) Analyzing the influence of the organization's climate on agricultural extension performance in the implementation of the Serasi program in Tanjung Lago Subdistrict, Banyuasin Regency.

\section{METHODS OF RESEARCH}

This research was conducted in Tanjung Lago Subdistrict, Banyuasin Regency. The location of the research was determined deliberately (purposive) with the consideration that the sub-district is a rice farming center area and most of its areas follow the Serasi Program. The research was conducted from February to April 2021. The number of respondents was 108 people consisting of 9 agricultural extension and 99 farmers. Sampling using multistage sampling, by means of PPL sampling is done purposively using the census method, the number of PPL samples is 9 people. Farmer sampling was conducted at Gapoktan in 9 villages that participated in the Serasi program and was built by 9 PPL. From 9 villages each taken 11 samples of farmers using random sampling sample method. Data retrieval is done through interviews and quizoner filling. Data collection was conducted by applying the method (1) Observation at the research sample location, (2) Interview using questionnaire guidelines for farmers who participated in the Serasi program and (3) Documentation during the research process. The data collected in this study are primary and secondary data, both qualitative and quantitative.

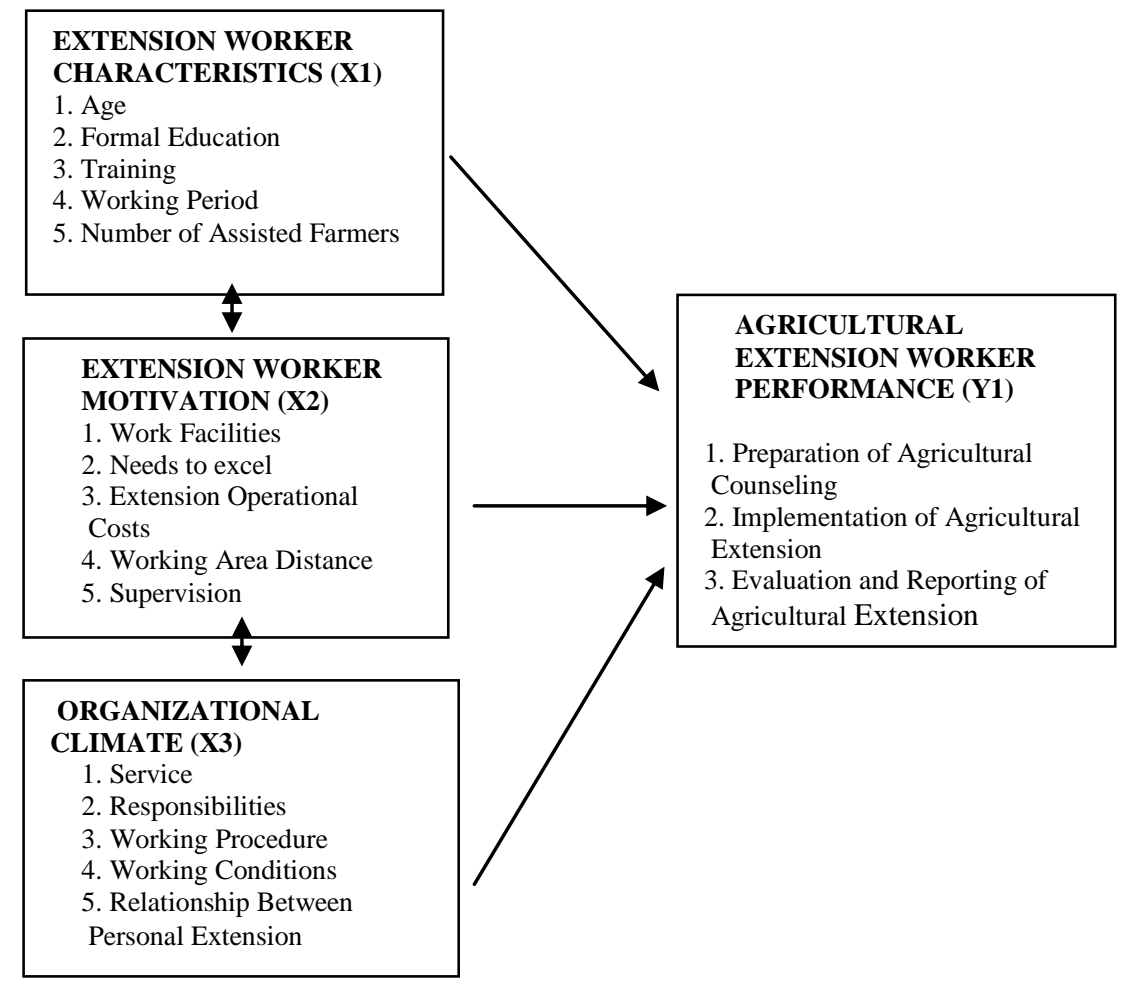

Figure 1 - Diagrammatic Approach Model

Note:

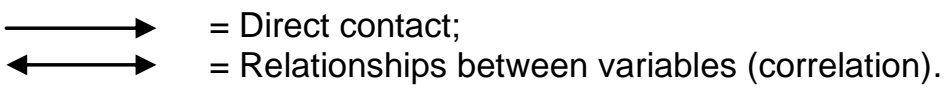

Primary data needed in the form of data related to variables analyzed. The variables in this study were free variables $(X)$ and bound variables $(Y)$. Free variables $(X)$ include: extension characteristics, extension motivation and the climate of the extension organization. The bound variable $(Y)$ in this study is the performance of agricultural extensionists, a model of biased digaramtik approach seen in Figure 1. Each variable consists of an assessment 
indicator, namely on the characteristic variables identified indicators are age, education level, number of farmers assisted, the number of trainings followed and the working period of agricultural extensionists. The motivation variables identified are work facilities, outstanding needs, operational costs of work, area of work, and supervision. The organization's climate variables identified include services, responsibilities, working procedures, working conditions and relationships between personal agricultural extensionists. The performance variables identified are agricultural extension preparation, implementation of agricultural counseling and evaluation and reporting of agricultural extension results.

Data analysis is performed by measuring variable indicators and hypothetical test analysis. Analysis of variable indicator measurement of extension performance is done by likert scale method which is divided into three categories, namely less good, good and very good. The work interval value for agricultural extension performance (variable $Y$ ) can be seen in Table 1. In the agricultural extension performance variable there are 3 assessment indicators with a total of 17 questions. The first indicator is the preparation of agricultural counseling with a total of 7 questions that include: making a learning plan in implementing the Serasi program; formulating the results of specific technological needs at locations that suit the needs of farmers; develop a clear, measurable and realized work plan; develop counseling programs that accommodate the needs of farmers; develop counseling methods in accordance with the counseling materials and characteristics of farmers; collect data about the community in the location to be able to participate in the program and invite local farmers to participate in the program that has been implemented.

The second indicator is the implementation of agricultural counseling with a total of 8 questions that include: conducting social action for agricultural counseling; maximize available extension media; understand and listen to farmers; explain, inspire, thank and be tolerant of farmers; encourage and help farmers to progress and achieve goals; discipline and motivate farmers; harmonize farmers or farmer groups that have different characters and bring together an action in the program in order to be one common goal. The third indicator is the evaluation and reporting of the results of counseling with a total of 2 questions that include: evaluating the implementation of agricultural extension and making a report on the results of the implementation of agricultural extension.

The hypothesis test analysis was conducted with SEM (Structural Equation Modeling) analysis which includes evaluation of measurement model (outer model) and evaluation of structural model (inner model) with SmartPLS application version 3.0. Sugiyono (2010) suggests that descriptive analysis is done to determine the value of a self-contained variable, either one variable, or more (independent) without making comparisons, or connecting with other variables. Evaluation of the measurement model (outer model) is done with validity test and reliability test. Evaluation of structural model (inner model) is done with t-statistical test and $P$ Value.

Table 1 - Class Interval Value for Measuring Agricultural Extension Performance (Variable Y)

\begin{tabular}{|c|c|c|c|c|c|c|c|c|c|}
\hline \multirow[b]{2}{*}{ No } & \multirow[b]{2}{*}{ Variable } & \multirow[b]{2}{*}{$\begin{array}{l}\text { Item of } \\
\text { Quest }\end{array}$} & \multirow[b]{2}{*}{ Min } & \multirow[b]{2}{*}{ Max } & \multirow[b]{2}{*}{ NR } & \multirow[b]{2}{*}{ PI } & \multicolumn{3}{|c|}{ Kategori } \\
\hline & & & & & & & $\begin{array}{l}\text { Less } \\
\text { Good }\end{array}$ & Good & Very good \\
\hline 1. & Agricultural Extension Performance & 17 & 17 & 51 & 34 & 11,33 & $\begin{array}{l}17,0- \\
28,33\end{array}$ & $\begin{array}{l}28,34- \\
39,67\end{array}$ & $\begin{array}{l}39,68- \\
51,0\end{array}$ \\
\hline
\end{tabular}

Measurement model evaluation criteria (outer model) as follows: (1) Loading factor value $>0.70$ for convergent validity test. (2) The AVE (Average Variance Extracted) value > 0.50 for discriminant validity test. (3) Composite reliability value $>0.70$ for confirmatory research. (4) Cronbach's alpha value $>0.70$ for confirmatory research (Ghozali, 2011). Structural model evaluation is done by looking at t-test statistics. Statistical test determination criteria $t$ (ttest) ie if the value of $\mathrm{P}$-Value $<0.05$ (thitung $>$ ttabel $5 \%$ ) then the construct is said to have a real effect and if the value of $\mathrm{P}$-Value $>0.05$ (thitung $<\mathrm{t}$-tabel $5 \%$ ) then the construct is said to have no real effect. 


\section{RESULTS AND DISCUSSION}

The variables in this study consisted of: extension characteristics (X1), motivation (X2), organizational climate (X3), and agricultural extension performance $(\mathrm{Y})$. In this study used several indicators in each variable measured. The indicators identified are age (X1.1), education level (X1.2), number of assisted farmers (X1.3), number of trainings followed (X1.4) and agricultural extension work period (X1.5). The motivation variables identified are work facilities (X2.1), achievement needs (X2.2), operational costs of work (X2.3), area of work area (X2.4), and supervision (X2.5). The organization's climate variables identified include service (X3.1), responsibility (X3.2), working procedures (X3.3), working conditions (X3.4) and relationships between agricultural extension personnel (X3.5).

Performance is the performance of work or work results (output) both quality and quantity achieved by a person unity period of time in carrying out his work duties in accordance with the responsibilities given to him (Mangkunegara, 2006). Performance reflects how well employees meet the requirements of a job. Performance is often misinterpreted as an effort that reflects the energy expended, performance is measured in terms of results (Setyadi, 2004). Indicators of Agricultural Extension Performance Assessment (PPL) based on Regulation of the Minister of Agriculture No. 91/Permentan/OT.140/9/2013 are as follows: Preparation of Agricultural Extension, Implementation of Agricultural Extension and Evaluation and Reporting of Agricultural Extension. The results of the achievement of the extension kierja score are seen in the Table 2 below. Based on the table below obtained the results that the performance of agricultural extension workerin the implementation of the Serasi program in Tanjung Lago Subdistrict is in the category of very good.

Table 2 - Extension Worker Performance Achievement Score

\begin{tabular}{|c|c|c|c|c|c|c|c|}
\hline \multirow[t]{2}{*}{ No } & \multirow[t]{2}{*}{ Rating Indicators } & \multicolumn{3}{|c|}{$\begin{array}{l}\text { Respondent's } \\
\text { Answer }\end{array}$} & \multirow{2}{*}{$\begin{array}{l}\text { Total } \\
\text { Score }\end{array}$} & \multirow[t]{2}{*}{ Average } & \multirow[t]{2}{*}{ Category } \\
\hline & & 1 & 2 & 3 & & & \\
\hline 1. & Preparation of Agricultural Extension & & & & & & \\
\hline a. & Make a learning plan in counseling & 0 & 0 & 99 & 297 & 3,0 & Very good \\
\hline b. & $\begin{array}{l}\text { Formulating the results of specific technology needs in a location that } \\
\text { suits the needs of farmers }\end{array}$ & 0 & 11 & 88 & 286 & 2,89 & Very good \\
\hline C. & Develop a clear, measurable and realized work plan & 0 & 0 & 99 & 297 & 3,0 & Very good \\
\hline d. & Develop counseling programs that accommodate the needs of farmers & 0 & 11 & 88 & 286 & 2,89 & Very good \\
\hline e. & $\begin{array}{l}\text { Develop extension methods that are in accordance with the extension } \\
\text { materials and characteristics of farmers }\end{array}$ & 0 & 55 & 44 & 242 & 2,44 & Very good \\
\hline f. & $\begin{array}{l}\text { Collect data about people in these locations to be able to join the } \\
\text { program }\end{array}$ & 0 & 22 & 77 & 275 & 2,78 & Very good \\
\hline \multirow[t]{2}{*}{ g. } & $\begin{array}{l}\text { Invite local farmers to participate in the Serasi program that will be } \\
\text { implemented }\end{array}$ & 0 & 22 & 77 & 275 & 2,78 & Very good \\
\hline & & & & & & 19,78 & Very good \\
\hline 2. & Implementation of Agricultural Extension & & & & & & \\
\hline a. & Conducting social action for agricultural extension & 0 & 55 & 44 & 242 & 2,44 & Very good \\
\hline b. & Maximize available extension media & 0 & 55 & 44 & 242 & 2,44 & Very good \\
\hline c. & Understanding and listening to farmers & 0 & 11 & 88 & 275 & 2,78 & Very good \\
\hline d. & Explaining, inspiring, grateful and tolerant of farmers & 0 & 44 & 55 & 254 & 2,57 & Very good \\
\hline e. & Encourage and help farmers to progress to achieve their goals & 0 & 11 & 88 & 275 & 2,78 & Very good \\
\hline f. & Discipline and motivate farmers & 0 & 11 & 88 & 275 & 2,78 & Very good \\
\hline g. & Harmonize farmers or farmer groups that have different characters & 0 & 44 & 55 & 254 & 2,57 & Very good \\
\hline \multirow[t]{2}{*}{ h. } & Maintain an action in the program to be one common goal & 0 & 22 & 77 & 275 & 2,78 & Very good \\
\hline & & & & & & 21,14 & Very good \\
\hline 3. & Evaluation and Reporting of Agricultural Extension Results & & & & & & \\
\hline a. & Evaluating the implementation of agricultural extension & 0 & 44 & 55 & 254 & 2,57 & Very good \\
\hline \multirow[t]{2}{*}{ b. } & Make a report on the implementation of agricultural extension & 0 & 44 & 55 & 254 & 2,57 & Very good \\
\hline & & & & & & 5,14 & Very good \\
\hline \multicolumn{2}{|c|}{ Total Score } & & & & 4.558 & 46,06 & Very good \\
\hline
\end{tabular}

In Table 2 indicates that the performance of agricultural extension worker in the implementation of the Serasi program is in the category of very good with an average value of 46.06. The performance of agricultural extension worker was measured from 3 indicators and the results show that agricultural extension workerare very capable in counseling farmers on the implementation of the Serasi program. It is shown by PPL has fully made data on potential areas and agroecosystems in the form of maps of target areas, maps and potential target areas, the planned schedule of counseling activities in each target area. The 
results of this study are in line with alamsyah research (2018) stated that ppl performance in Banyuasin regency has a score of 22.48 which means ppl performance is good enough or able to carry out duties as extension, PPL performance is seen from 4 indicators namely planning, implementation and evaluation. The above statement is also supported by Arbi and Sriati (2017) in a journal entitled Analysis of Field Agricultural Extension Performance in the Community Food Distribution Institute Program in Makarti Jaya Subdistrict, BanyuasinSumatera Selatan District stated that the performance level of Field Agricultural Extension (PPL) in Makarti Jaya Subdistrict banyuasin district is classified as sufficient criteria with an average Work Performance Value (NPK) of 71.43. Here is a description of assessment indicators on the performance of agricultural extension workerin the implementation of the Serasi program in Tanjung Lago Subdistrict, Banyuasin Regency.

Preparation of agricultural extension indicators have an average score of 19.78 with very good category. Program planning conducted by extension workers in this case is the Serasi program is considered very good by farmers. This is proven by the creation of data on the potential of regions and agro ecosystems, so as to utilize local resources marked by all Poktan in the region that meets the Serasi program has been registered to become a Serasi program actor. PPL also always make RKTPP (Annual Work Plan of Agricultural Extension) and develop agricultural programs together and very active in the preparation of RDKK (Group Needs Defenitif Plan) to each farmer group within the ppl target area. The preparation of RDKK is carried out by deliberation and consensus by the Management of farmer groups, members, and PPL as supervisors. RDKK is usually arranged jointly, namely RDKK Subsidized Fertilizer and Seed Assistance. PPL plays an active role in increasing the capacity of farmers, increasing the class of farmer groups, and the growth of new farmer groups. From these things cause the trust of farmers to follow the Serasi program after the socialization of Serasi program planning.

Indicator of Implementation Agricultural extension have an average score of 21.14 with an very good category. Farmers consider that the extension has done social action Serasi program has been very good to the farmers. Good interaction to farmers involving the ranks of agricultural government also adds integrity of counseling among farmers. The extension method applied in Tanjung Lago Sub-district is an ANJANGSANA method (Planned visit from the extension to the target site), Plot Demonstration; Demonstration Farm; Sarsehan pulpit at BPP Tanjung Lago Office and group services on social media with extension. The purpose of the plot demonstration is to set an example for farmers around him to apply new technologies in agriculture. The purpose of the farm demonstration is to improve the skills and knowledge of members of the group and give the surrounding farmers contah apply new technology through group cooperation. The purpose of the area demonstration is to improve the knowledge and skills of farmers group members through cooperation between farmer groups to implement new innovations in agriculture and provide examples for surrounding farmers. Mimbar sarasehan aims to conduct a consultation forum between farmers with the government organized periodically and continuously to discuss deliberations and reach agreements on matters related to the implementation of government programs and farmer activities in the framework of agricultural development, in this case BPP Tanjung Lago held in a period of 1 time in 2 weeks. Based on the interview results most farmers find it very helpful to use these methods in solving problems in the field. Farmers consider the extensionists have been very capable in terms of receiving criticism and aspirations from farmers, able to motivate to achieve certain goals which in this case is the success of the Serasi program and the extension has been able to attract farmers' sympathizers to succeed the Serasi program. PPL also conducts deliberations and consensus to maintain harmony between poktan members so that farmers can avoid conflict with extension workers and fellow poktan members.

Indicators of evaluation and reporting of agricultural extension results have an average score of 5.14 which is in the category of very good. This is proven by the evaluation and reporting of agricultural extension results in the implementation of the Serasi program in each village has been collected and accounted for to the banyuasin district government. In the report described in detail starting from the list of poktan members with complete identities 
who received assistance from the Serasi program, accountability and complete documentation of the distribution of Serasi program assistance in the form of dolomite, fertilizer, herbicides, pesticides, water pumps, seeds, as well as the process of making land irrigation conducted by farmers with the direction of the extension.

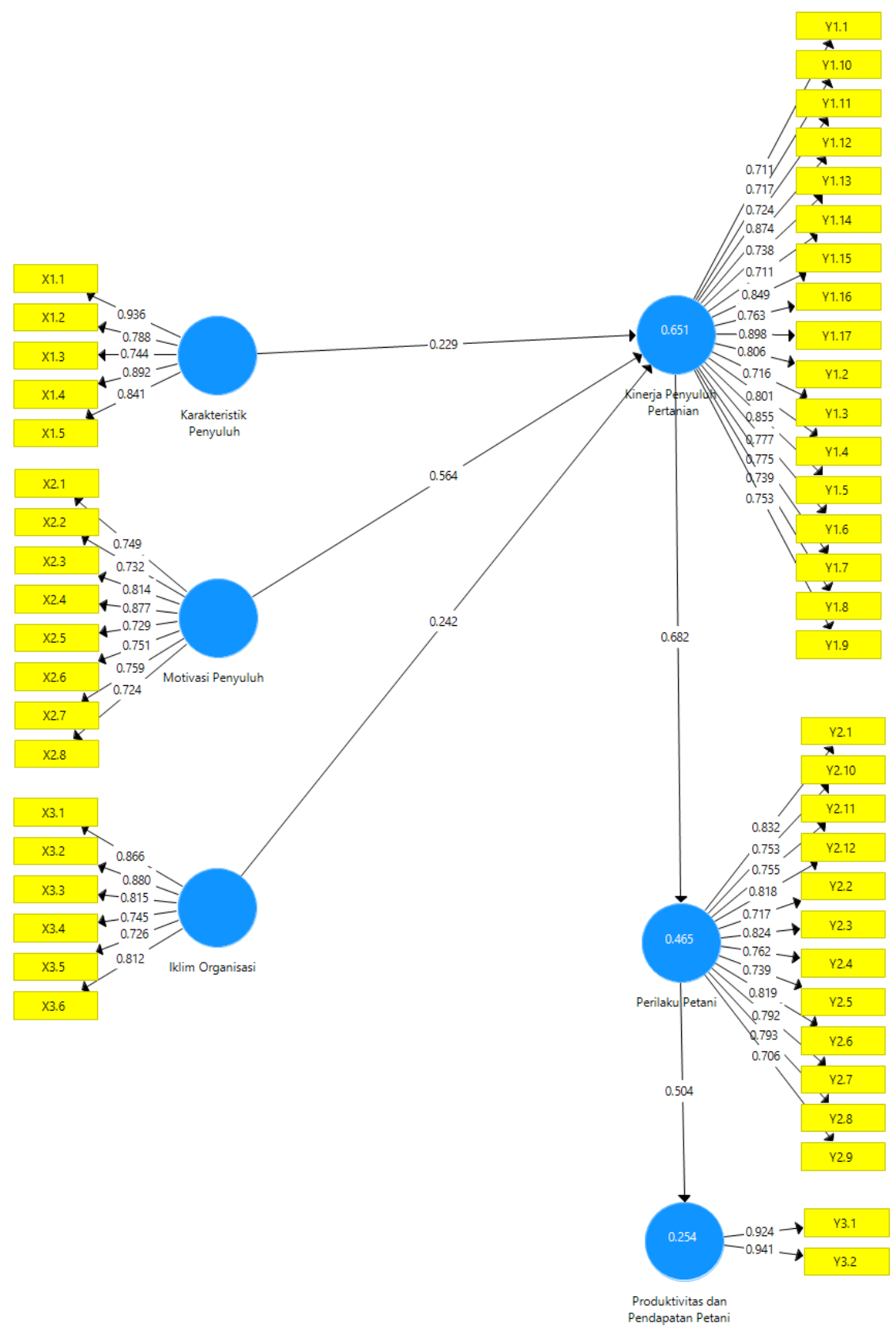

Figure 2 - Structural Model Research

Evaluation of measurement models is used to check the validity and reliability of the indicators that make up variables. An indicator is declared valid if it has a loading factor above 0.5 against the intended construct. Validity testing for reflective indicators uses correlations between item scores and variable scores. Measurements with reflective indicators indicate a change in an indicator in a variable if another indicator on the same variable changes (or is excluded from the model). Reflective indicators are suitable for measuring perception so this study uses reflective indicators. The structural model of research to see the validity of indicators variabels in this research was showed in Figure 2. 
In Figure 2 indicates that the loading factor provides a value above the recommended value of 0.5 . The result of the outer loading value between the question item and the largest variable is 0.936 in the $\mathrm{X} 1.1$ indicator. Item questions on $\mathrm{X} 1.1$. in this study is age. The result of the outer loading value between the question item and the smallest variable is 0.711 for the $\mathrm{Y} 1.1$ and $\mathrm{Y} 1.14$ indicators. Item questions on $\mathrm{Y} 1.1$. in this study is the performance of agricultural extension workerin performing social actions while the question indicator on Y1.1. in this research is the performance of agricultural extension workerin encouraging and helping farmers to progress and achieve goals. Means that the indicators used in this study are valid or have met the convergent validity. Based on the results of niai outer loading in the tabael above shows that all indicators have been declared valid to measure the construct because the outer loading value exceeds 0.5 . The discriminant validity test results can be calculated through ave values that must be greater than 0.5 and use Fornell and Larcker criteria scores where if the ave square root value of each variable is greater than the correlation value between variables with each other in the model. Discriminant validity test results can be seen in Table 3.

Table 3 - Discriminant Validity, Composite Reliability and Cronbach's alpha Test Results

\begin{tabular}{lllll}
\hline Variable & AVE Value & VAVE Value & Composite Reliability & Cronbach's Alpha \\
\hline Extension Characteristics & 0,591 & 0,768 & 0.924 & 0.897 \\
\hline Extension Motivation & 0,607 & 0,779 & 0.920 & 0.901 \\
\hline Climate Organization & 0,711 & 0,843 & 0.919 & 0.893 \\
\hline Agricultural Extension Performance & 0,655 & 0,809 & 0.963 & 0.959 \\
\hline
\end{tabular}

Based on the Table 3 obtained ave values more than 0.50 (AVE > 0.50) and square root values AVE has greater than the correlation between variables with each other so that the test results discriminant validity has a very good value. The result of ave squared AVE value is the most tinngi is the organization's climate variable while the lowest value is the extension characteristic variable. Reliability tests are conducted by looking at the composite reliability value of indicators that measure variables. Composite Reliability results will show a realistic result if it is above 0.7 whereas for Cronbach's alpha is above 0.6. The table above shows the result that all variables have a Composite Reliability value greater than 0.7 and Cronbach's alpha is more than 0.6. In Composite Reliability the highest value is the agricultural extension performance variable of 0.963 while the lowest value is the organization's climate variable of 0.919. At Cronbach's alpha the highest value is the agricultural extension performance variable of 0.959 while the lowest value is the organization's climate variable of 0.893 . Based on the table above can be concluded that all constructs in this study have good reliability and have met the criteria.

Structural model evaluation is done to determine the relationship between variables. Testing of structural models is conducted by hypothesis test by looking at t-statistical values and $\mathrm{P}$ Value which can be described in detail in Table 4.

Table 4 - Hypothesis Test

\begin{tabular}{lllll}
\hline Relationships Between Variables & Variable Coefficient & t-statistic & $P$ Value & Description \\
\hline $\mathrm{X} 1 \rightarrow \mathrm{Y} 1$ & 0,229 & 3,411 & 0.001 & positive and significant \\
\hline $\mathrm{X} 2 \rightarrow \mathrm{Y} 1$ & 0,564 & 6,171 & 0.000 & positive and significant \\
\hline $\mathrm{X} 3 \rightarrow \mathrm{Y} 1$ & 0,242 & 2,795 & 0.000 & positive and significant \\
\hline
\end{tabular}

Based on the data in Table 4 it can be explained that the relationship and influence of extension characteristics (X1) on the performance of agricultural extension worker(Y1) with a coefficient of line of 0.229 , t-statistics of 3,411 and $P$ Value of 0.001 . Relationship and influence of extension motivation (X2) on agricultural extension performance ( $\mathrm{Y} 1$ ) with a coefficient of 0.564 and t-statistics of 6,171 and $P$ Value of 0.000 . The relationship and influence of the organization's climate $(\mathrm{X} 3$ ) on the performance of agricultural extension worker(Y1) with a coefficient of track of 0.229 , t-statistics of 3,411 and P Value of 0.000 . 
positive and very significant effect shown through the positive coefficient of track value and tstatistic $>1.96$.

The characteristic of the extension is a feature that is naturally attached to a person who develops regularly so that behavior becomes more consistent and easy to notice (Isna, 2017). According to Sugiarta (2017) said that individual characteristics that affect the competence of agricultural extensionists, among others: age, level of formal education, training followed, number of farmers assisted, the working period of agricultural extension. In this study, the characteristics of extension workers (X1) had a positive and significant effect on the Performance of Agricultural Extension Workers ( $Y 1)$ because the coefficient of the path was 0.229 , $t$ statistics were 3,411 or greater than $t$ table $=1.96$ and also the $p$ value of 0.001 or less than 0.05 . The performance of agricultural extension workeris strongly influenced by the characteristics of extensionists which include age (X1.1), formal education level (X1.2), number of assisted farmers (X1.3), number of trainings followed (X1.4) and the working period of agricultural extension worker(X1.5). The above research results are in line with Arifianto's research (2017) which shows that the characteristics of agricultural extension workerhave a positive effect on the performance of agricultural extensionists, which is indicated by a probability value of $=0.019<0.05$. The characteristics of this study are formed from indicators that include: education, experience and training. The same results were also obtained through Bahua research (2010) which showed that the characteristics of extensionists have a real effect on the performance of agricultural extensionists, meaning that the change in characteristics contributes to determining the poor performance of agricultural extension workerwith a real coefficient of influence of -0.30 at $\alpha=0.05$. Characteristics in the study are age, working period and number of assisted farmers. Martin's research (2019) also stated the same result that the characteristics of agricultural extension workerdirectly affect performance, as evidenced by the coefficient of track value of 0.120 which means that there is a significant direct influence between the characteristics of agricultural extension workerto the performance of agricultural extension workerby $1.44 \%$. Indicators of agricultural extension worker characteristics in this research are age, working time, use of social media, availability of advice and infrastructure and active communication with farmers.

Motivation in humans is both intrinsic motivation that is the motivation from the inside to do something and extrinsic motivation that is the motivation from outside the self to do something attached to everyone, including agricultural extensionists. The desire to learn and improve intelligence, skills, attitudes and skills is driven by certain motivations that can be intrinsic or extrinsic. An agricultural extension is encouraged by his intrinsic motivation to have high competence in counseling always sharpen his reasoning by studying, reading, attending trainings, seminars, discussions, demonstrations and so on. This intrinsic impulse can become stronger if there is also an accompanying extrinsic impulse (Djamarah, 2002). In this study, motivation (X2) had a positive and significant effect on Agricultural Extension Performance $(\mathrm{Y} 1)$ because the coefficient of track value was 0.564 , t statistics were 6,171 or greater than table $t=1.96$ and also $p$ value of 0.000 or less than 0.05 . Motivation variables measured in work motivation factors include work facilities (X2.1), achievement needs (X2.2), extension operational costs (X2.3), work area (X2.4) and supervision (X2.5). Based on this, it can be explained that the motivational factors of work positively affect the performance of agricultural extension workerin the implementation of the Serasi program in Banyuasin Regency. The above results are in line with Sapar research (2012) which shows that the motivation of agricultural extension workerhas a real effect on the performance of counseling. This means that the motivation of agricultural extension workeralso determines the good of their performance with a real coefficient of influence of 0.24 in the $\alpha=0.05$. In this research which includes the motivation of the extension is the need for achievement and the needs of affiliates. The above statement was also reinforced by Erwina (2018) who stated that the influence of motivation on the performance of agricultural extension workeris positive and significant and has a t-value greater than 1.96 which is 3.96 . This indicates that the better the motivation of agricultural extensionists, the better the performance produced by agricultural extension. Agustina's research results (2017) also stated the same results that the motivation 
of extension worker has a real effect on the competence of agricultural extension workerby 0.47 which is evident in the $\alpha=0.05$, In research that becomes an indicator of motivational factors is the need for achievements that include the urge to excel or excel. and the need for affiliates that includes the desire to be accepted by others in a work-based or residential environment.

Organizational climate factor in the agricultural extension environment have a fairly important role in maximizing the performance of an extension. The organizational climate is also often referred to as organizational culture, according to Sule and Sefullah (2008), organizational culture is basically the values and norms embraced and run by an organization related to the environment in which the organization carries out its activities. Previous researches have discussed the influence of organizational culture on performance but on the performance of company employees or employees. According to Nayak and Barik (2013) organizational culture has a role in employee job satisfaction. A culture that fits and matches managerial values must be developed by the company in order to create job satisfaction for employees, thereby increasing employee commitment to the organization. And in the end the level of job satisfaction in these employees can provide more benefits for the company so that the company is able to compete with other companies.

In this study, the organizational climate (X3) had a positive and significant effect on agricultural extension performance $(Y)$ because the coefficient of the path was $0.242, t$ statistics were 2,795 or greater than table $t=1.96$ and also the $p$ value was 0.000 or less than 0.05 . These results are obtained through indicators of service (X3.1), responsibility (X3.2), working procedures (X3.3), working conditions (X3.4) and relationships between personal extensions (X3.5). The above results are in line with Sugiarta's research (2017) which showed that the organization's climate factors positively influenced the performance of agricultural extension workerwith the results of coefficients of the path with a value of 0.276 and t-statistics of 2,813 or t-statistics $>2.64$. The variables measured in this organization's climate are service, responsibility and interpersonal relationships of extension. The above statement is also reinforced by Siregar (2010) showing that the work culture has a very strong relationship with the performance of agricultural extension workerwho have an effect of $62 \%$.

\section{CONCLUSION}

Based on the results and discussions in this study, it can be concluded as follows: (1) The performance of agricultural extension worker in the implementation of the Serasi program in Tanjung Lago Subdistrict Banyuasin Recency is very good catagory with an average score of 46.06. (2) The characteristic factors of extension worker have a positive and significant effect on the performance of agricultural extension worker in the implementation of the Serasi program in Tanjung Lago Subdistrict Banyuasin (3) Motivational factors positively and significantly affect the performance of agricultural extension worker in the implementation of the Serasi program in Tanjung Lago Subdistrict Banyuasin regency and (4) Organizational climate factors positively and significantly affect the performance of agricultural extension worker on the implementation of the Serasi program in Tanjung Lago Subdistrict Banyuasin Regency.

Based on the results of the analysis and discussion that has been done in this study, it can be given some suggestions as follows: (1) The performance of agricultural extension worker in Tanjung Lago Subdistrict Banyuasin is very good to continue to be maintained even though the Serasi program has been implemented so as to support the performance of local extension institutions / institutions that carry out other programs both from the region and programs from the center and (2) In addition to the characteristic factors, work motivation and organizational climate of the extension that is considered in improving the performance of agricultural extension worker, it is also expected that the support of facilities and infrastructure to improve the ability of agricultural extension worker. 


\section{REFERENCES}

1. Agustina, F., Zahri, I., Yazid, M., Yunita. 2017. Determinant Factors Of Agricultural Extension Competence In The Implementation Of Good Agricultural Practices In Bangka, Belitung Province. Russian Journal of Agriculture and Socio-Economic Science. 9 (69) : 231-238.

2. Alamsyah, I., Malini, H., dan Aryani, D., 2018. Kinerja Penyuluh Pertanian Lapangan (PPL) dan Kaitannya terhadap Pendapatan Usahatani Padi di Kabupaten Banyuasin. Prosiding Seminar Nasional Lahan Suboptimal 2018, Palembang 18-19 Oktober 2018 "Tantangan dan Solusi Pengembangan PAJALE dan Kelapa Sawit Generasi Kedua (Replanting) di Lahan Suboptimal" Editor: Siti Herlinda, et. al. ISBN: 978-979-587-801-8 313.

3. Arbi, M., dan Sriati., 2017. Analisis Kinerja Penyuluh Pertanian Lapangan dala Program Lembaga Distribusi Pangan Masyarakat di Kecamatan Makarti Jaya Kabupaten Banyuasin Sumatra Selatan. Jurnal Penyuluhan, 13 (2) : 125-132.

4. Arifianto, S., Satmoko, S., Setawan, B.M. 2017. Pengaruh Karakteristik Penyuluh, Kondisi Kerja, Motivasi Terhadap Kinerja Penyuluh Pertanian dan Pada Perilaku Petani Padi Di Kabupaten Rembang. Jurnal Agrosocionomics. 1 (2) :166-180. ISSN : 2580-0566

5. Bahua, M.I., Jahi, A., Asngari, PS., Saleh, A., Purnaba, I., 2010. Faktor-faktor yang Mempengaruhi Kinerja Penyuluh Pertanian dan Dampaknya pada Perilaku Petani Jagung Di Provinsi Gorontalo. Jurnal IImiah Agropolitan. 3 (1): 293-303.

6. Darmawan, C.A., Gayatri, S, Satmoko, S. 2020. Pengaruh Perilaku Petani Dalam Penerapan Sapta Usahatani Terhadap Produktivitas Padi Di Kelompok Tani Vanda Subur, Kota Semarang. Tesis. Universitas Diponegoro.

7. Departemen Pertanian, 2013. Peraturan Menteri Pertanian Nomor 91/Permentan/Ot.140/9/2013. Pedoman Evaluasi Kinerja Penyuluh Pertanian. Berita Negara Republik Indonesia Tahun 2013 Nomor 1153 : Jakarta.

8. Dinas Pertanian Kabupaten Banyuasin. 2019. Pedoman Teknis Optimasi lahan Rawa.

9. Djamarah B. \& Syaiful., 2002. Psikologi Belajar. Jakarta : Pt Rineka Cipta.

10. Erwina. 2018. Pengaruh Motivasi Terhadap Kinerja Penyuluh di Luwu Utara. Jurnal Of Economic Management and Accounting. 1 (2). E-ISSN : 2615-5850

11. Ghozali, I. 2012. Structural Equation Modeling Metode Alternatif dengan Partial Least Square. Edisi 3. Semarang: Universitas Diponegoro.

12. Isna, W., Rusidah, S., \& Wahyuni, N., 2017. 100 Pengaruh Karakteristik Individu, Karakteristik Pekerjaan dan Karakteristik Organisasi terhadap Kepuasan Kerja Karyawan Koperasi (Sumber Data Mandiri) Muara Teweh Kalimantan Tengah. Jurnal Bisnis dan Pembangunan, 6 (2). ISSN 2541-178.

13. Kementan. 2019. Program SERASI Mengubah Lahan Menjadi Produktif Mendapat Dukungan DPR. pertanian.go.id [online]. Published 2019. https://www.pertanian.go.id/home/?show=news\&act=view\&id=3838. [Diakses December 22 2020].

14. Leilani, A., dan A. Jahi. 2006. Kinerja penyuluhan pertanian di beberapa Kabupaten Provinsi Jawa Barat. Jurnal Penyuluhan 2 (2): 99-106.

15. Mangkunegara., 2006. Evaluasi Kinerja SDM. Bandung: PT. Refika Aditama.

16. Martin, H., Suwarto, Sapja, A., 2019. Analysis Of Determinant Performance Of Agricultural Extension Agents In Lebak District, Banten Province Of Indonesia. Russian Journal of Agriculture and Socio-Economic Science. 8 (92) : 281-286

17. Nayak B, Barik A. 2013. Assessment of the link between Organizational culture and job satisfaction (Study of an Indian Public Sector).International Journal of Information, Business and Management. 5 (4).

18. Padmanagara, S., 2012. Bapak Penyuluhan Pertanian. Pengabdi Petani Sepanjang Hayat. Jakarta Selatan: PT. Duta Karya Swasta Gedung Arsip.

19. Sapar., 2011. Faktor-Faktor Yang Memengaruhi Kinerja Penyuluh Pertanian Dan Dampaknya Pada Kompetensi Petani Kakao Di Tempat Wilayah Sulawesi Selatan. Disertasi. Sekolah Pascasarjana. Institut Pertanian Bogor. 
20. Setyadi, Simamora \& Henry., 2004. Manajemen Sumber Daya Manusia. Yogyakarta: STIE YKPN.

21. Siregar, A.N \& Tri R.S. 2010. Hubungan Antara Motivasi Dan Budaya Kerja Dengan Kinerja Penyuluh Pertanian di Kabupaten Subang, Provinsi Jawa Barat. Jurnal Penyuluhan Pertanian. 5 (1).

22. Sugiarta P, Igaa Ambarawati, I Gede Setiawan Adi Putra. 2017. Pengaruh Kinerja Penyuluh Pertanian Terhadap Perilaku Petani Pada Penerapan Teknologi Ptt Dan Produktivitas Padi Di Kabupaten Buleleng.Jurnal Manajemen Agribisnis. 5 (2). Issn: 2355-0759

23. Sudiadnyana I, I Gede Setiawan Adi Putra. 2019. Pengaruh Kinerja Penyuluh Pertanian Terhadap Perilaku Petani Pada Penerapan Tanam Jarwo 2:1 Di Kecamatan Banjarangkan Kabupaten Klungkung. Jurnal Manajemen Agribisnis. 7 (1). E- ISSN: 26847728

24. Sule, E.T \& Saefullah K., 2008. Pengantar Manajemen. Jakarta (ID): Kencana.

25. Wahjuti., 2007.Metodologi Penyuluhan Pertanian Partisipatif. Malang: Sekolah Tinggi Penyuluhan Pertanian (STPP). 